\title{
Rare presentation of necrotising fasciitis and streptococcal toxic shock syndrome by group A streptococcus
}

\author{
Saqib Saeed, Sara Alothman, Leaque Ahmed, Brian Donaldson
}

Department of Surgery, Harlem Hospital Center, New York, New york, USA

\section{Correspondence to Dr Saqib Saeed, \\ saqib.saeed08@gmail.com}

Accepted 8 September 2017

\section{DESCRIPTION}

A 44-year-old healthy male presented to the emergency room with a 6-day history of right medial thigh pain and itching. Examination revealed mild erythema with superficial swelling, but no tenderness (figure 1A). Vital signs were stable. White cell count (WBC) was $11.2 \times 10^{9} / \mathrm{L}$ with no other significant laboratory abnormality. During the next 6 hours, his erythema and swelling extended to involve the whole thigh with the patient getting septic (spiking $102^{\circ} \mathrm{F}$, heart rate $110 / \mathrm{min}$ and blood pressure $118 / 79 \mathrm{~mm} \mathrm{Hg}$ ). WBC trended up to $23 \times 10^{9} / \mathrm{L}$ and lactate $4.7 \mathrm{mmol} / \mathrm{L}$. MRI was performed which showed possible myositis (figure 1B). Despite intravenous antibiotics (penicillin and vancomycin) and resuscitation, his clinical condition deteriorated rapidly. In the next 4 hours, patient was taken to the operative room for fasciotomy and exploration. Intraoperatively, patient was found to have fasciitis. Necrotic tissue was removed.
Postoperative day 1 , he developed a diffuse maculopapular rash and bullae involving right lower extremity (figure 1C). In the next 24 hours, his rash progressed to involve lower abdomen. He developed acute respiratory distress syndrome requiring intubation. Antibiotic regimen was switched to clindamycin/linezolid and the patient was taken to the operating room for a second look and further debridement. All the necrotic tissues were debrided. For the next couple of days, patient required multiple debridements (figure $2 \mathrm{~A}$ ).

After his condition stabilised, his wound was closed by a skin graft (figure 2B,C). The wound culture was positive for Group A streptococcus pyogenes. Patient was discharged home with oral antibiotics.

Toxic shock syndrome (TSS) is a rare fatal disease with mortality reaching as high as $70 \%$. Most frequent cause of TSS is Gram-positive

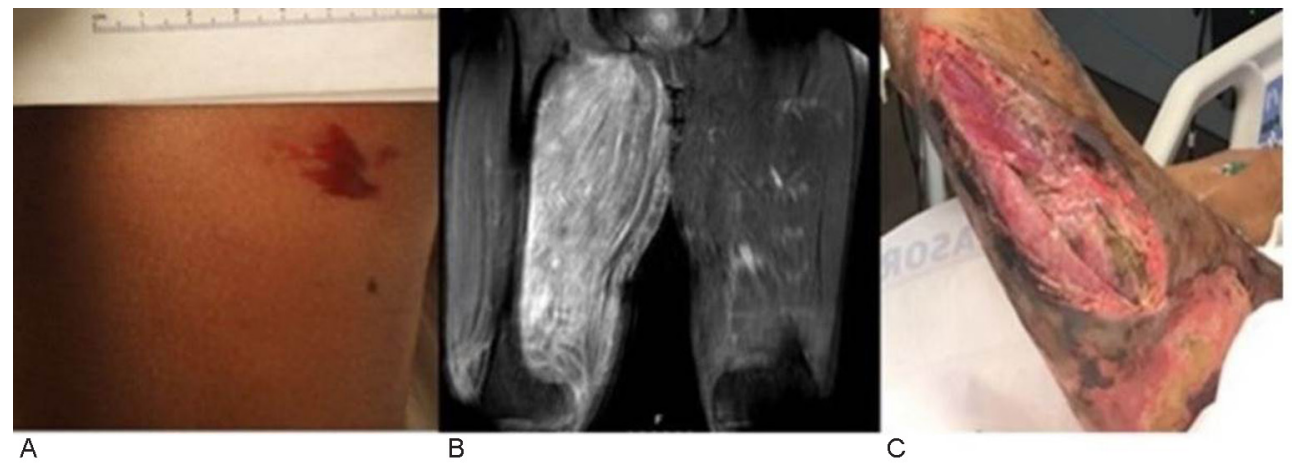

Figure 1 (A) Right medial thigh with mild erythema. (B) MRI of the lower extremities with inflammatory changes involving the right thigh. (C) Post-debridement skin changes.

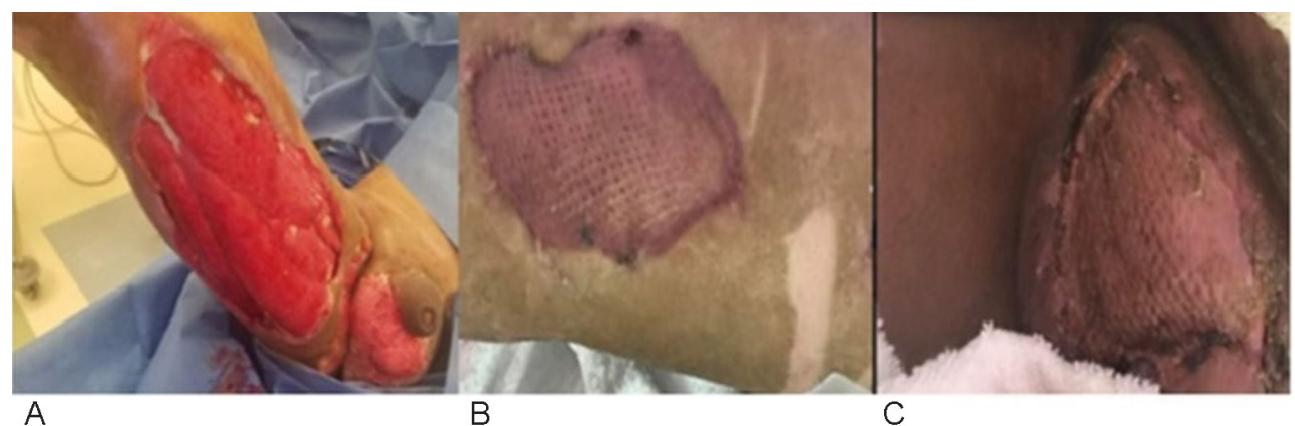

Figure 2 Skin grafting of the wound. Part A shows wound granulatin after multiple debridments; parts B and C show wound after skin grafting. 
staphylococcus while the incidence of Streptococcus resulting in the TSS is 3.5 cases per 1000 persons. $^{1}$

Most cases result from a minor trauma where the portal of entry can be established, but non-penetrating trauma can also result in soft tissue infections. In our case, there was no portal of injury and patient had no comorbidities.

Streptococcal TSS presents with pain that precedes physical findings on exam. ${ }^{2}$ Disease can spread rapidly secondary

\section{Learning points}

- Toxic shock syndrome (TSS) is a rapidly spreading fatal disease characterised by shock and multiorgan failure with mortality reaching up to $70 \%$.

- Both penetrating and non-penetrating trauma can cause streptococcal TSS.

- Early recognition, septic shock management with fluid resuscitation and empiric antibiotics therapy with urgent surgical debridement is crucial for a successful outcome and survival. to streptococcus pyogenes super antigen resulting in cytokine storm. Diagnosis is made when streptococcus species are isolated from a sterile site along with signs/symptoms of septic shock and diffuse erythematous macular rash.

Early recognition with urgent surgical debridement along with intravenous antibiotics and resuscitation is required for successful outcome.

Contributors All the authors have contributed to the management of the patient and the write up of the manuscript, study concept/writing paper and editing of the paper. LA was responsible for the management and review. BD was the principle investigator.

Competing interests None declared.

Patient consent Obtained.

Provenance and peer review Not commissioned; externally peer reviewed.

(c) BMJ Publishing Group Ltd (unless otherwise stated in the text of the article) 2017. All rights reserved. No commercial use is permitted unless otherwise expressly granted.

\section{REFERENCES}

1 Nelson GE, Pondo T, Toews K-A, et al. Epidemiology of invasive group A streptococcal infections in the United States, 2005-2012. Clinical Infect Dis 2016;63:478-86.

2 Burnham JP, Kollef MH. Understanding toxic shock syndrome. Intensive Care Med 2015:41:1707-10.

Copyright 2017 BMJ Publishing Group. All rights reserved. For permission to reuse any of this content visit http://group.bmi.com/group/rights-licensing/permissions.

BMJ Case Report Fellows may re-use this article for personal use and teaching without any further permission.

Become a Fellow of BMJ Case Reports today and you can:

- Submit as many cases as you like

- Enjoy fast sympathetic peer review and rapid publication of accepted articles

- Access all the published articles

- Re-use any of the published material for personal use and teaching without further permission

For information on Institutional Fellowships contact consortiasales@bmjgroup.com

Visit casereports.bmj.com for more articles like this and to become a Fellow 